\title{
Andrzeja Stawara Brzozowskiego portret podwójny
}

Paweł Rams 


\section{Interpretacje}

\section{Andrzeja Stawara Brzozowskiego portret podwójny}

Paweł Rams

TEKSTY DRUGIE 2017, NR 5, S. 246-263

DOI: $10.18318 /$ td.2017.5.17

P owojenna recepcja myśli Stanisława Brzozowskiego jest w moim mniemaniu jednym z najciekawszych zjawisk intelektualnych tego okresu. Dyskusje toczące się wokół dziedzictwa autora Ptomieni doskonale oddają ich dynamikę. Lata 1945-1948 są bowiem próbą reinterpretacji jego spuścizny w kontekście tragicznych wydarzeń II wojny światowej. Co więcej, są próbą uczynienia z Brzozowskiego elementu projektu nowej Polski nawet wtedy, gdy poszczególne jego idee ujawniały swoją drugą, mniej chwalebną twarz. Nadzieje na uczynienie autora Głosów wśród nocy klasykiem i ważną postacią polskiej powojennej lewicy brutalnie rozwiewa Paweł Hoffman, który w swym autorytatywnym artykule umieszczonym w „Nowych Drogach” w 1947 roku zalicza polskiego filozofa przełomu wieków do sił reakcyjnych, sankcjonując jego pozycję jako wroga nowego ustroju i na długie lata blokując wszelkie dyskusje'.

1 O recepcji Brzozowskiego w latach 1945-1955 piszę w: Pamięć lewicy. Polska myśl socjalistyczna przełomu XIX i XX wieku kontra stalinowski
Paweł Rams - absolwent filologii polskiej i filozofii na Uniwersytecie Jagiellońskim, doktorant w Instytucie Badań Literackich PAN. Pod kierunkiem Michała Głowińskiego przygotowuje rozprawę na temat recepcji myśli Stanisława Brzozowskiego w Polsce w latach 1945-1989. Jest członkiem zespołu Nowej Panoramy Literatury Polskiej oraz Ośrodka Studiów Kulturowych i Literackich nad Komunizmem działającymi przy Instytucie Badań Literackich PAN. Kontakt: pawel. rams@ibl.waw.pl 
Powrót do Brzozowskiego następuje wraz z przełomem 1956 roku. Jednym z najważniejszych tekstów wychodzących po Październiku jemu poświęconych (odważę się stwierdzić, że nawet w całej dotychczasowej recepcji jego pism) jest esej Andrzeja Stawara (właśc. Edwarda Janusa) O Brzozowskim $\mathrm{z} 1960 \mathrm{roku}^{2}$. Na wagę tego tekstu składają się dwa czynniki: jeden pozatekstowy, drugi tekstowy. Pierwszy z nich dotyczy biografii Stawara i wydarzeń historycznych, które spowodowały wyraźne zmiany w jego postrzeganiu filozofii Brzozowskiego. Trzeba bowiem pamiętać, że Stawar był przed wojną jednym z najzagorzalszych krytyków Brzozowskiego i jego wpływu na młodą polską inteligencję lewicową, a jednocześnie wpływowym krytykiem literackim o jawnie komunistycznych poglądach. Urodzony w rodzinie bezrolnych chłopów, którzy na początku wieku przenieśli się do Warszawy w poszukiwaniu pracy, dość szybko zaangażował się w działalność Komunistycznej Partii Robotniczej Polski, do czego predestynowało go nie tylko pochodzenie, ale także podejmowanie pracy głównie w charakterze robotnika. Jak wielu jemu podobnych kształcił się we własnym zakresie. Musiał przerwać naukę i zacząć zarabiać na swoje utrzymanie, nie mogąc liczyć na pomoc rodziny. W okresie międzywojennym działał w organach partyjnych, angażował się w życie polityczne i społeczne także jako publicysta i krytyk literacki (współpracował m.in. z „Wiadomościami Literackimi”). Zajmował się także tłumaczeniem z literatury rosyjskiej. W 1931 za swoją działalność redakcyjną (najpierw w „Dźwigni”, potem w „Miesięczniku Literackim”) został aresztowany i przebywał w więzieniu dwa miesiące. To jednak nie odstraszyło go od podejmowania dalszej pracy publicystycznej. W latach 1934-1936 współwydawał „Pod Prąd”, a za swoje publikacje tam zamieszczone został oskarżony przez partię o trockizm, co spowodowało zerwanie współpracy. W 1939 roku uczestniczył w kampanii wrześniowej, po jej upadku osiadł w Budapeszcie, ciągle udzielał się społecznie i publicystycznie. W 1945 roku

rozrachunekz reakcją. Przypadek Pawła Hoffamana, w: Historie afektywne i polityki pamięci, red. E. Wichrowska, A. Szczepan-Wojnarska, R. Sendyka, R. Nycz, Wydawnictwo Instytutu Badań Literackich PAN, Warszawa 2015, oraz Między historiq a biografiq̨. Funkcjonowanie myśli Stanisława Brzozowskiego w latach 1945-1948, „Pamiętnik Literacki” 2017 Z. 1.

2 A. Stawar O Brzozowskim, w: tegoż O Brzozowskim i inne szkice, Czytelnik, Warszawa 1961, s. 7-112. Fragmenty tekstu ukazywały się na łamach prasy zarówno przed jak i po 1960 roku: O Brzozowskim , "Polityka” 1959 nr 8, s. 1, 8-9; W matni bezdziejowości, „Polityka” 1959 nr 11; Etyka i ideologia, „Polityka” 1959 nr 12; Myśl i wzruszenie, „Polityka” 1959 nr 13; Brzozowski krytyk , Nowa Kultura" 1960 nr 48, s. 1, 11; Brzozowski krytyk: poglady na powieść $i$ krytyka , Nowa Kultura” 1960 nr 50, s. 3, 9; Brzozowski. Fragmenty, "Kultura i Społeczeństwo” 1961 nr 1, s. 3-23. 
wrócił do kraju. Pisał recenzje i zabierał głos w najważniejszych ówczesnych dyskusjach (m.in. o rodowodzie inteligencji polskiej, toczącej się na łamach „Kuźnicy” w 1946 roku). Po odmowie złożenia samokrytyki został objęty zakazem druku, a na łamy prasy powrócił dopiero w 1955 roku. Umarł w 1961 roku podczas pobytu we Francji u Giedroycia, z którym omawiał możliwość wydania przedwojennych szkiców ${ }^{3}$.

Biografia Stawara, typowa pod wieloma względami dla marksistów kształtujących swoje poglądy przed II wojną światową, miała ogromny wpływ na aparat krytyczny, którym posługiwał się w badaniach literatury. Doskonałym przykładem tej metody twórczej jest artykuł o Brzozowskim, który ukazał się w „Dźwigni” w 1928 roku. Na tekst ten wielokrotnie powoływali się badacze dorobku autora Ptomieni, zasadne więc będzie zrekonstruowanie zawartej w nim metodologii i argumentacji. Jednocześnie pozwoli to wskazać na różnice między nim a późniejszym o ponad trzydzieści lat tekstem. Swój przedwojenny szkic rozpoczyna Stawar od wiele mówiącej konstatacji

[Brzozowski - przyp. P.R.] w pewnym sensie nie przestał być pisarzem współczesnym. Wpływ jego ciąży dziś bezwzględnie silniej niż kiedykolwiek - co do tego nie może być dwóch zdań. Ogromna zależność publicystyki literackiej dnia dzisiejszego przejawia się choćby w formach zewnętrznych: w stylu, sposobie podania myśli, zakresie poruszonych tematów itd. Trudniejszym do uchwycenia byłby wpływ polityczny Brzozowskiego, większy, niż to się może zdawać z pozoru. Oddziaływanie Brzozowskiego idzie tu w dwóch kierunkach: zarówno na pewne odłamy burżuazji i drobnomieszczaństwa, jak i na ruch robotniczy w Polsce, gdzie odgrywa dużą rolę, zwłaszcza przez kształcenie umysłów młodzieży. ${ }^{4}$

Zacytowany fragment odgrywa w tekście dwojaką rolę: z jednej strony jest stwierdzeniem pewnego stanu rzeczy, z drugiej staje się punktem wyjścia krytycznych rozważań nad owym wpływem. Stawar nie ukrywa własnego zdziwienia faktem, że pisma autora Ptomieni są z jednej strony inspiracją dla Mariana Zdziechowskiego ${ }^{5}$, którego uznaje za przedstawiciela „obszarniczej

3 Wszystkie informacje biograficzne podajęza: Współcześni polscy pisarze i badacze literatury. Słownik biobibliograficzny, red. J. Czachowska, A. Szałagan, t. 7, WSiP, Warszawa 2001, s. 449-450.

4 A. Stawar Brzozowski, w: tegoż Szkice literackie. Wybór, PIW, Warszawa 1957, s. 73.

5 W tekście Stawara pojawia się „prof. Kazimierz Zdziechowski”, co zapewne jest błędem. Kazimierz Zdziechowski był bowiem pisarzem, bratem Mariana Zdziechowskiego, profesora Uni- 
konserwy i monarchistę" ${ }^{\text {, }}$ z drugiej zarówno dla młodych, jak i dla doświadczonych działaczy ruchu komunistycznego?. Wpływ ten tłumaczy Stawar m.in. swoistym monopolem, jaki na pisanie o marksizmie miał wówczas Brzozowski. Międzywojenny krytyk bardzo jasno określa, z jakiej perspektywy będzie analizował spuściznę po autorze Legendy Młodej Polski

Toteż rzeczą ważniejszą od analizowania poszczególnych poglądów lub też uwydatniania sprzeczności, których sam Brzozowski ani myślał się wypierać, będzie określenie pewnych cech typu społecznego, uwydatniających się w działalności pisarza. Rzuca to światło na stosunek Brzozowskiego do konkretnych zagadnień społecznych, na stosunek jego do marksizmu, który właściwie jest tu najważniejszy. To pozwoli na określenie właściwego charakteru działalności pisarza. ${ }^{8}$

Przytoczony fragment jest jasną deklaracją ze strony Stawara o wykorzystaniu narzędzi marksistowskich do analizy wpływu „rzekomego marksisty” na działaczy komunistycznych okresu międzywojennego. Będzie go przy tym interesowało nie powoływanie się Brzozowskiego na swoich filozoficznych idoli, lecz „wewnętrzne prawa jego myślenia, zasady nie tylko miar, ale i ustalonych faktów"'. Za szczególnie przyciągającą czytelników cechę Brzozowskiego uznaje Stawar „odosobnienie, brak poczucia przynależności organizacyjnej, powodujące stan charakterystycznej depresji, wrażenia zawieszenia w pustce - związane zarazem z zastanawiającym oderwaniem się od spraw życiowych"10, który zdaniem autora szkicu - ku jego nieskrywanemu zdziwieniu, dosięga także ówczesną lewicę polską. Stawar kolejno wymienia najważniejsze zarzuty pod adresem Brzozowskiego. Jest to oskarżenie o dogmatyzm, kaznodziejstwo, etyczny patos, uprawianie swoistego pamiętnikarstwa filozoficznego, uczynienie z badania własnej psychiki metodologii czy wreszcie

wersytetu Wileńskiego. Za omyłką ze strony autora przemawia również to, że to Marian, a nie Kazimierz, byłautorem książki o Brzozowskim.

6 Tamże.

7 Tamże, s. 74-75,

8 Tamże, s. 76.

9 Tamże, s. 77. Określenia te są cytatem z Brzozowskiego piszącego w ten sposób o Sainte-Beuvie. 
oderwanie od faktów życia codziennego. Każdy z tych zarzutów jest oczywiście odpowiednio uargumentowany, jednak korpus ten nie stanowi trzonu krytyki. Głównym zarzutem jest bowiem sprzyjanie nie rewolucji społecznej, ale interesom burżuazji chcącej rewolucję proletariacką zatrzymać. To właśnie ten element wpływa na całościową ocenę autora Idei i oskarżenie go nie tyle nawet o bezpośrednie zagrożenie dla ruchu robotniczego, co uwiedzenie osób o poglądach rewolucyjnych konserwatywną ideologią ukrytą pod pięknymi, acz niewiele znaczącymi hasłami. W ostatnich partiach artykułu pada stwierdzenie o ogromnym podobieństwie między Brzozowskim i Sienkiewiczem, jednak znaczenie tego pierwszego

leży w tym właśnie, że oddziaływał na skalę bez porównania szerszą i że działał na te grupy, na które połaniecczyzna już działać nie mogła. Dziś, gdy robota jego wydaje jaskrawe rezultaty - trzeba bardziej niż kiedykolwiek oceniać i zwalczać tę złowrogą propagandę, która niejednokrotnie dociera blisko rdzenia sił ludowych, ponieważ w formach pseudorewolucyjnych daje wyraz przesłankom propagandy faszystowskiej."

Tym właśnie stwierdzeniem kończy się tekst z 1928 roku. Od zestawienia Brzozowskiego z Sienkiewiczem zaczyna się z kolei o ponad trzydzieści lat późniejszy tekst. Zastosowanie tego zabiegu formalnego ma za zadanie podtrzymać wcześniejsze zarzuty (autor unika w ten sposób powtórzenia). Jest jednocześnie wskazaniem na ewolucję, jaką w stosunku do Brzozowskiego i jego myśli przeszedł Stawar. Tę dwoistość oddaje także sama struktura tekstu, która jest znacznie rozszerzoną wersją eseju przedwojennego, powtarzającą wiele z wcześniejszych ataków. Jest jednakże dużo łagodniejsza w swojej wymowie, nie widać w niej młodzieńczej zapalczywości i rozemocjonowania, ale nade wszystko jest dużo bardziej rozbudowana argumentacyjnie i zawiera spory fragment dotyczący Brzozowskiego jako pisarza i krytyka literackiego, których to fragmentów nie było we wcześniejszej wersji. Komparatystyczne ujęcie obydwu tekstów daje świadectwo zmianie, jaka zaszła w sposobie myślenia Stawara pod wpływem wydarzeń życiowych i historycznych. Jednym z najlepszych przykładów - a zarazem świadectwem ogromnej uczciwości intelektualnej autora pracy $O$ Gałczyńskim - jest wycofanie się z twierdzenia, jakoby Brzozowski był prekursorem faszystów. Nie znaczy to, że przestał o nim myśleć krytycznie, jednak wobec ataku, jakiego padł ofiarą w okresie 
stalinizmu postanawia zweryfikować tezę, którą zakończył swój przedwojenny szkic. W pracy z 1960 roku pisze tak:

W nowszej literaturze marksistowskiej spotykało się taki pogląd, który wszystkie sprzeczności, niekonsekwencje myślowe i polityczne Brzozowskiego wyjaśniał jako wynik z góry ułożonej taktyki, aby przy pomocy przechwytywania idei czasu stworzyć system w zasadzie reakcyjny, antyrewolucyjny. W ten sposób próbowano niejednokrotnie załatwić jego złożony niewątpliwie stosunek do marksizmu. Czytając takie oświetlenie można by wnioskować, że Brzozowski był niezwykle mądrym i przenikliwym reakcjonistą, który wiedzę polityczną czasów miał, jak to się mówi, w końcach palców, posiadał z góry obmyślone ujęcie problemów wszelkiego rodzaju. Schlebiając proletariatowi, zagrywając ideami marksistowskimi zmierzał świadomie do sparaliżowania rozwoju klasowej ideologii mas robotniczych. Na pozór potwierdzenie tej interpretacji można by znaleźć u samego Brzozowskiego, który chętnie podkreślał celowość założeń owej pracy i jej konsekwencje w dążeniu do ostatecznych celów. W wyniku tego Brzozowski bywał oceniany przez polityków jako bardzo mądry, bardzo przenikliwy dywersant polityczny. Ten zbyt uproszczony pogląd nie znajduje uzasadnienia w rzeczywistości. Brzozowski, publicysta wielkiego talentu, nie miał linii wytkniętej w sposób tak konsekwentny, jak podawał niekiedy w swych książkach, a jego wielki wpływ wynikał nie z jakiejś wyrafinowanej dyplomacji, ale dużej plastyczności, wrażliwości na impulsy środowiska. ${ }^{12}$

Zacytowany fragment odnosi się oczywiście do kampanii, jaką wytoczyli Brzozowskiemu staliniści z Pawełm Hoffmanem i Adamem Schaffem na czele, ale nie tylko pod ich adresem kierowane są te słowa. Stanowią bowiem swego rodzaju autokrytykę. Nie można tego stwierdzić z niezachwianą pewnością, jednak z dużym prawdopodobieństwem można przyjąć, że Stawar po wielu latach, po wydarzeniach, których był uczestnikiem, świadkiem oraz ofiarą, nazywanie Brzozowskiego protofaszystą uznaje za niemożliwe do utrzymania i niesprawiedliwe.

Zmiana ta nie przekreśla krytycznego stosunku Stawara do autora Legendy Młodej Polski. Świadectwem tego jest pozostawienie bez zmian większości

12 A. Stawar O Brzozowskim, s. 19-20. Wszelkie dalsze cytaty pochodzące z tego wydania oznaczał będę jako OB z podaniem numeru strony. 
zarzutów z przedwojennego szkicu. Cechą charakterystyczną artykułu z „Dźwigni” było bardzo mocne osadzenie przedmiotu krytyki w realiach społecznych, politycznych i ekonomicznych. Element ten zostaje rozwinięty i jeszcze mocniej wykorzystany w tekście późniejszym. Podobnie jak przed wojną Stawar występuje przeciwko Brzozowskiemu z pozycji działacza zaangażowanego w przedwojenny ruch komunistyczny, dla którego marksizm jest nie tyle kierunkiem filozoficznym, co konkretną wskazówką, w jaki sposób należy działać, by zmienić położenie klasy robotniczej. Marks i Engels nie są dla Stawara metafizykami, lecz twórcami teorii ekonomicznej i społecznej mającej na celu przebudowę relacji klasowych ${ }^{13}$. Dlatego też najważniejszym i najciekawszym elementem argumentacji jest próba szerokiego zarysowania tła społecznego, z warunkami ekonomicznymi, społecznymi i walką klasową nie tylko czasu, w którym żył i tworzył Brzozowski, ale także czasów wcześniejszych i późniejszych. Zatrzymajmy się na jednym z najbardziej charakterystycznych fragmentów dających wyobrażenie o metodologii Stawara. Chodzi o ostrą krytykę Sienkiewicza przeprowadzoną przez Brzozowskiego. Większość krytyków w mniejszym bądź większym stopniu przychylała się do opinii młodopolskiego filozofa, stawiając co najwyżej zarzuty o zbyt ostry język i zapalczywość krytyczną, którą niejednokrotnie kładziono na karb młodego wieku krytyka. A oto jak sprawę tę przedstawia Stawar:

Dla Brzozowskiego ideologia Sienkiewicza była symbolem trójlojalności. Szczególnie używał sobie na biologicznym optymizmie autora „Trylogii” przy rezygnacji politycznej. Nie była to przecie sprawa tylko temperamentu pisarskiego Sienkiewicza. Polemika dotyczyła nie tylko spraw literackich, ale pojmowania najważniejszych zagadnień bytu społecznego. Różnice wystąpią tym jaskrawiej, gdy uwzględnimy rys biograficzny obu pisarzy - wspólne punkty wyjścia. Tak Sienkiewicz jak i Brzozowski byli synami zdeklasowanych ziemian, jako młodzi ludzie obciążeni skutkami tej deklasacji. Ale warunki były odmienne i koleje ideologiczne różne. Sienkiewicz po krótkim okresie radykalizmu zaczął wyrażać te żywioły, które przyszły do siebie po klęsce z nawrotem do konserwatywnej

13 Można zaryzykować tezę, że dla Stawara nieprzekonująca pozostała rewizja marksizmu w duchu antropocentryzmu, za której protoplastę Leszek Kołakowski, Bronisława Baczko oraz Andrzej Walicki uznawali właśnie Brzozowskiego Stawar pozostawał wierny tej wizji marksizmu, która mocniej akcentowała walory polityczne niż filozoficzne i to w jej duchu dokonuje krytyki autora Płomieni. 
ideologii ziemiańskiej i do niektórych idei literatury szlacheckiej. Tak to przynajmniej oceniano $\mathrm{w}$ potocznym rozumieniu - w istocie sprawa była bardziej skomplikowana ze względu na koneksje pozytywistyczne pisarza. Chodziło tu raczej o fuzję elementów społecznych, które odniosły korzyści z rozwoju kapitalizmu w drugiej połowie XIX wieku, co w warunkach zaborów łączyło się z rezygnacją z aktywności politycznej. $[\mathrm{OB}, 11]$

Po tej ogólnej charakterystyce następuje dokładne przedstawienie sytuacji społeczno-ekonomicznej warunkującej zdaniem Stawara taką, a nie inną postawę. Mamy więc podkreśloną rolę klęsk powstań narodowych, które chociaż miały poważne konsekwencje w sferze ideowej i symbolicznej, to "nie zatrzymały procesu przeobrażeń społeczno-gospodarczych w Polsce" [OB, 11]; uwydatniona zostaje rola bardzo dużego przyrostu naturalnego na ziemiach polskich w porównaniu do innych krajów Europy [OB, 11]. Stawar wskazuje, że trójlojalizm miał poparcie przede wszystkim wśród posiadaczy, gdyż zabezpieczał on ich interesy ekonomiczne i klasowe [OB, 12]. Podkreśla jednocześnie, że wynikający z tego rozwój przemysłu odbijał się pozytywnie także na położeniu ogółu ludności [OB, 12]. Ważnym dla Stawara wydarzeniem jest utworzenie SDKPiL i PPS [OB, 12-13]. Ogromne znaczenie ma także różny charakter cenzury w różnych zaborach, co skutkowało zupełnie odmiennymi możliwościami publicystycznymi i wydawniczymi [OB, 13]. Wreszcie pisze Stawar o powstaniu nowej warstwy społecznej, jaką był „proletariat w białych kołnierzykach", odróżniający się od robotników wykształceniem, ale tak jak oni pozbawionym majątku i utrzymywaniem się głównie z pracy najemnej $[\mathrm{OB}, 13]$. Dopiero zakreślenie tak szerokiej panoramy społecznej XIX wieku umożliwia zrozumienie ataku Brzozowskiego na Sienkiewicza i jednocześnie dowodzi, że wbrew pozorom obydwie postacie łączy bardzo dużo. Zostaje tym samym podtrzymany zarzut Stawara z przedwojennego tekstu. Nieuwzględnienie czynników społecznych, politycznych i ekonomicznych sprawia jego zdaniem, że jedna z najważniejszych kampanii Młodej Polski okazuje się niczym więcej niż wydmuszką, słowną bitwą o symbole, niedotykającą realnych problemów kraju i ludności żyjącej pod zaborami. W tym kontekście wagi nabiera jedna z podstawowych tez tekstu Stawara, zaczerpnięta bez zmian z wcześniejszego artykułu, mówiąca o w gruncie rzeczy tradycjonalistycznym charakterze myśli autora Płomieni. Opinia ta najlepiej wyrażona została w poniższym fragmencie: 
Brzozowski pozostał tradycjonalistą, nawet w swoim dążeniu do „naprawiania” myśli polskiej, unowocześniania jej. Podłoże społeczne myśli, wyrażającej ściśle pewne stosunki, rozumie, określa częstokroć bardzo trafnie nawet, ale w praktyce działa w myśl tradycji. Jako myśliciel stanowił zamknięcie romantyzmu polskiego - choć po części musiałoby się go rozpatrywać z punktu widzenia ironii romantycznej. $[\mathrm{OB}, 43]$

Opinia ta może zadziwiać w kontekście przyjmowanego zazwyczaj przekonania, że Brzozowski był przede wszystkim publicystą i filozofem walczącym z wszelkimi przejawami polskiego tradycjonalizmu i zaściankowości, za których wyraziciela uważany jest zazwyczaj Sienkiewicz. Dla Stawara w świetle przyjmowanych przez niego marksistowskich założeń jest to pogląd oparty na nieporozumieniu, wynikającym z braku krytycznej i pogłębionej refleksji nad spuścizną autora Legendy Młodej Polski. Stanowisko to najlepiej oddaje następujący fragment: „W końcu jednak walka ta była wypędzaniem diabła przez Belzebuba. Można zauważyć, że na miejsce wygnanych starych mitów, Brzozowski w swej działalności wprowadza nowe, zdolniejsze do życia, no i uwspółcześnione. Prowadziło to właściwie do odnowienia tradycyjnej maszynerii pojęciowej" [OB, 46]. To, co wielu czytelnikom młodopolskiego filozofa jawiło się jako ostra walka ze świętościami polskiej tradycji, dla Stawara jest niczym innym niż stawianiem w miejsce jednych bożków innych. Pogląd ten w znaczący sposób odbiega od perspektyw, jakie przyjmowano w powojennej recepcji Brzozowskiego.

W swoim dowodzeniu Stawar wykazuje, że młodopolski krytyk w gruncie rzeczy nie wychodzi poza zaklęty krąg idei swojej epoki. Świadczyć ma o tym chociażby uleganie nastrojowości. Zarzut ten jest nieustannie podnoszony w kluczowych analizach dorobku Brzozowskiego. Posługując się nim, Stawar chce przekonać czytelnika, że jednym z filarów jego metody jest nie intelektualna przenikliwość, ale podleganie emocjom wywoływanym przez kolejne lektury. Jest to nieustanne obracanie się w przestrzeni nakreślonej przez własną psychikę, ,prowadzenie monologu wewnętrznego, rozłożonego na tysiące stron druku" [OB, 33]. Kolejny zarzut zaczerpnięty bez zmian z przedwojennego szkicu dotyczy obojętności Brzozowskiego wobec faktów życia społecznego, w którego przypadku „doświadczenie osobiste górowało nad społecznym" [OB, 26]. Po raz kolejny czytelnik spotyka się z tezą idącą w poprzek ogólnie przyjętym rozpoznaniom. 
Wymienione lejtmotywy krytyczne Stawara to jednak za mało, by przypisać mu ważną rolę w powojennej recepcji autora Ptomieni. To, co czyni z omawianego tekstu ważny głos w dyskusji, to wykorzystanie owych punktów do szerszej analizy krytycznej najważniejszych problemów, które interesowały Brzozowskiego. Stawar w odróżnieniu od wcześniejszych (i późniejszych) głosów, stara się wyjść poza zaklęty krąg interpretacji. Chce na nowo, przy użyciu marksistowskich narzędzi, dalekich jednakże od stalinowskiej ortodoksji, pokazać, że wiele z dotychczasowych analiz dorobku młodopolskiego filozofa ulega wytworzonej przez niego samego iluzji. Tak właśnie ma się sprawa z filozofią pracy. Stawar zajmuje się nią już w tekście z „Dźwigni", a swoją interpretację powtarza bez zmian w powojennym eseju. Mimo to krytyka ta zyskuje zupełnie inny charakter ze względu na odmienne warunki społeczno-polityczne. To, co w okresie przedwojennym można było postrzegać jako próbę włączenia się w polityczną walkę o prawa ludzi pracy, to w ustroju, w którym z założenia stanowili oni część przewodnią narodu, krytyka ta nabiera bardziej teoretycznych rozważań, ale jednocześnie może być uznana za krytyczny głos dotyczący współczesności. Nie zmienia to jednak podstawowej obserwacji, że Stawar nadal nie daje się uwieść metafizycznej wizji pracy Brzozowskiego. Idzie tu śladem notatek Nałkowskiego z Legendy Młodej Polski ${ }^{14}$, a także Karola Irzykowskiego, którzy jako pierwsi krytycznie patrzyli na zagadnienie pracy u autora Idei. Stawar, jak na marksistę przystało, poglądy na pracę Brzozowskiego krytykuje z pozycji jednostki uwikłanej w proces dziejowy, w tym przypadku robotnika, dla którego wysiłek fizyczny nie jest wykrawaniem przestrzeni wolności w chaosie natury, ale realnym, fizycznym trudem mającym na celu zyskanie środków do przeżycia, a nieodłącznie wiążącym się ze zmęczeniem, narażeniem na choroby, trwałą utratą zdrowia, a nawet śmiercią ${ }^{15}$. Poza tym, że Brzozowski zdaniem Stawara w swojej filozofii pracy posługuje się myśleniem teologicznym [OB, 6o], jego retoryka w dziwny sposób przypomina tę, stosowaną przez obszarników

14 Krytyka Legendy Młodej Polski dokonana przez Nałkowskiego, zdaniem Romana Rosiaka, wyprzedza argumenty, jakimi posłużył się w swoim sławetnym wystąpieniu Paweł Hoffman (R. Rosiak Stanisław Brzozowski w oczach Wacława Nałkowskiego , „Annales UMCS Sectio F Nauki Filozoficzne i Humanistyczne", Lublin, v: 16: 1961 [wyd. 1964], s. 94). Teza ta jest dość kontrowersyjna, jednak nie będę się nią bliżej zajmował w tym szkicu.

15 „Brzozowski propagując pracę jako taką, pracę dla pracy - zdaje się mało zwracać uwagi na człowieka, który pracuje. Zresztą życie tak czy owak jest strasznym dramatem, męką, tragedią - kwestie bytu pracownika schodzą na drugi plan wobec wielkiej pracy dla historii" (OB, 62). 
występujących przeciwko zniesieniu pańszczyzny ${ }^{16}$. Podsumowując - dla Stawara to, co dla wielu stało się największym osiągnięciem myśli Brzozowskiego, a więc jego koncepcja pracy, okazuje się w dużej mierze metafizyką pracy. Nie ma w sobie nic z realności, w niewielkim stopniu dotyka kondycji robotnika. Nie znaczy to, że krytyk odmawia tej koncepcji wszelkiej racji bytu. Rozprawia się jednak z jej mitem, który miał wpływ na ukształtowanie całego pokolenia lewicowej inteligencji.

Część eseju O Brzozowskim poświęcona ogólnej charakterystyce jego pisarstwa w aspekcie estetycznym została opublikowana już po II wojnie światowej. Stanowi najlepsze świadectwo ewolucji stosunku Stawara do Brzozowskiego. W okresie międzywojennym była to postawa nieprzejednana, oceniająca i w jakiś sposób niwelująca. Pamiętajmy jednak, że młody podówczas krytyk pochodzący z nizin społecznych, żyjący i tworzący w zupełnie odmiennych realiach, walczył z realnym zagrożeniem, jakim był wzrastający wpływ nacjonalizmu na robotników. Po okresie wojny i stalinizmu sytuacja przedstawia się już zgoła inaczej. Dlatego też inaczej rozłożone zostają akcenty. Nadal podtrzymuje on swoje mocno krytyczne stanowisko, jednak wyraża je w zupełnie inny sposób. Oto przykład:

Pisarstwo Brzozowskiego, w którym współcześni widzieli rysy genialności, jest zjawiskiem imponująco niewykończonym. Brzozowski powtarza tu dramat kultury nierzadki w naszym piśmiennictwie [...]. Niemniej sprzeczności oraz niekonsekwencje Brzozowskiego bywają bardziej interesujące niż niejedna wykończona gładko pośredniość. [OB, 88-89]

Fragment ten doskonale ilustruje, w jaki sposób ewoluowało myślenie Stawara o Brzozowskim. Nie była to radykalna wolta, odejście od wcześniej przyjmowanych założeń. Mamy do czynienia z próbą ujęcia dorobku Brzozowskiego z pozytywnymi i negatywnymi jej stronami. O tyle, o ile w przypadku rozważań młodopolskiego filozofa na tematy społeczne i polityczne opinia Stawara nadal pozostaje bardzo surowa, to postawa ta ulega

„Spróbujmy przeczytać jakąkolwiek argumentację inteligentnego obszarnika z lat trzydziestych, czterdziestych ubiegłego wieku przeciwko zniesieniu pańszczyzny. Jak subtelnie, a zarazem gorąco ludzie ci potrafili mówić o dostojeństwie pracy, o prawie człowieka do pracy i temu podobnych pięknych rzeczach. Podobnie było później, gdy chodziło o zwalczanie strajków robotniczych - padało wówczas mnóstwo pięknych słów [...]. Sławienie pracy jako takiej stało się wypraktykowanym od dawna sposobem kokietowania pracujących" (OB, 61). 
złagodzeniu w przypadku kompletnej oceny jego dorobku, w tym dorobku pisarskiego. W moim przekonaniu uprawnione jest powtarzane już kilkakrotnie twierdzenie, że zmiana ta była odpowiedzią na biograficzne i historyczne doświadczenia Stawara. W zupełnie nowej rzeczywistości stara się on spojrzeć na autora Legendy Mtodej Polski okiem nie tylko krytycznym, ale i rozumiejącym. Zabiegiem ułatwiającym zrozumienie sytuacji twórczej Brzozowskiego są wprowadzane przez Stawara szerokie panoramy społeczne, polityczne i ekonomiczne.

Jednym z najważniejszych elementów rozważań Stawara nad Brzozowskim-krytykiem jest głoszony przez tego ostatniego pogląd o nierozłączności formy i etyki, rozumianej przede wszystkim jako odpowiedzialność za kształtowanie rzeczywistości i poczucie, że swoim pisarstwem ma się na nią wpływ. Stawar z pewnym uznaniem pisze o tym poglądzie Brzozowskiego: „Krytyk podkreślał zasadę i dziś nie pozbawioną swoistej aktualności, stwierdzając, iż literatura wyrasta z doświadczeń rzeczywistych, to znaczy z nieurojonych doświadczeń rzeczywistości społecznej” [OB, 100]. Omawiany szkic dobitnie świadczy, że takie ujęcie było bliskie autorowi tych słów, zgadzało się z jego przekonaniami na temat roli sztuki w życiu społecznym. W tym jednym punkcie można z całą pewnością powiedzieć, że Brzozowski staje się mu w jakiś sposób bliski. Mowa tutaj jedynie o poglądach, ponieważ już o stylu, w którym autor Legendy Młodej Polski przekazuje swoje myśli, Stawar pisze jednoznacznie krytycznie

Styl Brzozowskiego, ciemny i miejscami zawikłany, uwypuklał główne punkty dowodzenia ze znaczną dozą egzaltacji, która udzielała się w momencie czytania [...]. Prace krytyczne Brzozowskiego grzeszą dogmatyzmem, skłonnością do wtłaczania materiału literackiego w schematy nie zawsze jednolicie stosowane. [OB, 104]

O Brzozowskim, pierwszy tak długi i wyczerpujący szkic, który ukazał się po 1956 roku kończy się w niezwykle charakterystyczny sposób:

Na wielu ocenach autora „Idei” zaciążyły gusty epoki, na sposobie wypowiedzi - stylizacja młodopolska. Niemniej prace jego wykazują dużo energii myślowej, choć użytej w sposób ekstensywny. W historii literatury pozostaje on jednym z głównych przedstawicieli naszej myśli krytycznej, a dorobek jego, przy swej nierównej wartości, i po dziś dzień ma swoje znaczenie. [OB, 112] 
Jeżeli przypomnimy sobie zakończenie artykułu z 1928 roku, to naszym oczom ukaże się nie tylko zupełnie inny Brzozowski, ale także zupełnie inny Stawar. W zakończeniu artykułu z „Dźwigni” młodopolski filozof został oskarżony o tendencje prefaszystowskie, w tekście z 1960 zaś spotyka się z uznaniem, choć nie bez zastrzeżeń, dla swoich zasług dla kultury polskiej. Postawa krytyczna Stawara zdecydowanie słabnie na rzecz postawy rozumiejącej, która wprawdzie była daleka od zachwytu, stara się jednak oddać sprawiedliwość Brzozowskiemu i wpływowi jego myśli na kulturę polską. Zmianę, o której tu mowa, możemy oczywiście przypisać dojrzalszej postawie i przemyśleniom, jakie poczynił autor eseju na przestrzeni trzydziestu lat. Z pewnością wpływ na zmianę perspektywy miały wydarzenia historyczne i życiowe o charakterze formacyjnym. Mamy tutaj do czynienia nie z zerwaniem, lecz reinterpretacją własnych poglądów. Bezwzględnie krytyczna (by nie rzec krytykancka) linia interpretacji ulega przekształceniu na rzecz wnikliwszej, doceniającej wkład autora Idei w polską kulturę. Nie jest to zerwanie z wcześniejszym stanowiskiem. W tym względzie Stawar trzyma się wypracowanej przez siebie metody marksistowskiej, koryguje jednak pewne założenia i oceny pod wpływem wydarzeń życiowych i historycznych. Nie ulega bowiem wątpliwości, że wojna, lata 1945-1948 oraz konieczność zamilknięcia w okresie stalinizmu wywarły ogromne wrażenie na tym nieprzeciętnym krytyku literackim i pozostawiły po sobie ślady w tekście z 1960 roku, który można - w ograniczonym zakresie - uznać za dokument osobisty.

Rozbudowana analiza oraz wyrażone przeze mnie uznanie dla Stawara jako krytyka i czytelnika Brzozowskiego mogłoby świadczyć, że szkic spotkał się z zainteresowaniem i wzbudził żywą dyskusję. Nadzieję taką żywił m.in. Jerzy Stempowski, który na antenie Radia Wolna Europa w 1961 roku wygłosił felieton na temat zbioru prac krytycznych Stawara ${ }^{17}$. Niestety tak się nie stało. Głos Stempowskiego był jednym z czterech, na które natrafiłem podczas kwerendy bibliotecznej, a które odnosiły się do powojennego szkicu Stawara. Głos ów jako jedyny dochodził spoza kraju, mógł więc wypowiedzieć to, co nie mogło zostać zwerbalizowane przez krytyków mieszkających w Polsce. Przede wszystkim w felietonie tym Stawar zostaje sportretowany jako marksista, ale marksista nieortodoksyjny, mający swoje własne zdanie i niekryjący się z nim, w konsekwencji czego musiał przed wojną zerwać współpracę

17 J. Stempowski Andrzej Stawar, „O Brzozowskim i inne szkice”, w: tegoż Felietony dla Radia Wolna Europa, Wydawnictwo Książkowe Twój Styl, Warszawa 1995, s. 7-10. 
z partią, po wojnie zaś, w okresie stalinizmu, zamilknąć na kilka lat ${ }^{18}$. Stempowski ceni omawianego autora przede wszystkich za "trzeźwość oglądu" przy jednoczesnym ciągłym definiowaniu się jako marksista. Za zasługę poczytuje mu chociażby uznanie dla literatury awangardowej i eksperymentalnej, która nie cieszyła się popularnością u ortodoksyjnych komunistów ${ }^{19}$. Główny esej zbioru nie staje się przedmiotem gruntownej analizy, zostaje jednak doceniona jego waga i znaczenie we współczesnych dyskusjach. Waga ta polega nie na wykazaniu ciągłej aktualności filozofii Brzozowskiego, ale na uchwyceniu realiów życia intelektualnego tamtych czasów z zaznaczeniem tła społecznego i ekonomicznego ${ }^{20}$.

Słów uznania nie szczędzi także Stefan Treugutt, pisząc o Stawarze-krytyku w następujący sposób:

Jakże mało w jego pisaniu erudycyjnej bufonady, retorycznego efektu, śmiałego skakania myśli... nie ma krytycznego „liryzmu” i samochwalstwa, tak pospolitego żonglowania własną osobą i własną sprawnością intelektualną. I jakże mocno obwarowana pewność swojego sądu! Z niezachwianym poczuciem rozsądnej sprawdzalności formułuje Stawar myśli jasne, na ogół proste (czasem nawet upraszczające) - na ogół zapisane w sposób bardzo skondensowany, „nabity” treścią, nie zawsze łatwy do czytania. Marksistowska metoda analizy faktów kultury nabiera pod piórem Stawara cech najprostszego wykładu rzeczy skomplikowanych - tak skomplikowanych, że nawet ich prosty, rozsądkowy wykład staje się monumentalnym spiętrzeniem współzależności i odniesień. ${ }^{21}$

Opinia ta wskazuje na mocne, marksistowskie ugruntowanie metody krytycznej Brzozowskiego, a jednocześnie docenia jej niezwykły kunszt. Treugutt wyszukuje podobieństwa między metodą krytyczną Stawara i Brzozowskiego ${ }^{22}$. Więcej nawet. Autor tej krótkiej wspomnieniowej noty ${ }^{23}$,

18

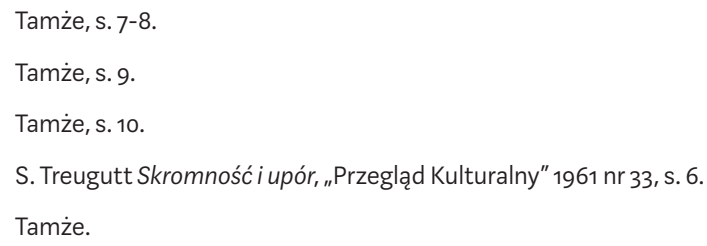


wyliczając zalety twórczości zmarłego krytyka, podkreśla jednocześnie zasadniczą zbieżność między obydwoma postaciami. Swoją opinię uzasadnia następująco:

Brzozowski jest dlatego przedmiotem badań, ponieważ „napisał on po swojemu ważny fragment biografii intelektualizmu polskiego". Stawar marksista i w publicystyce i w pracach z dziedziny historii literatury dalekich na pozór od problematyki dzisiejszej - zajmował się w gruncie rzeczy tym samym: historyczną genezą współczesności, częściami składowymi i tradycją „wszelkiego eksperymentu”, czyli naszego teraz. ${ }^{24}$

To zdumiewające zestawienie ma wykazać nie tylko wagę publicystycznej twórczości Stawara, jego doniosłej interpretacji myśli Brzozozwskiego, ale także, że owo zafascynowanie nie było zupełnie bezinteresowne. Wynikało bowiem bezpośrednio z doświadczeń osobistych. Pewne podobieństwo między obydwoma autorami wskazywał także Stempowski, pisząc, że „Stawar sam był heretykiem i to, co było heretyckie u Brzozowskiego, musiało go szczególnie pociągać" ${ }^{25}$. I chociaż teza ta wymagałaby lepszego uzasadnienia, to z pewnością kryje się w niej ziarno prawdy. W końcu na przedmiot badawczy nie wybiera się rzeczy zupełnie obojętnej.

Krótką notatkę w czasopiśmie „Świat” poświęca zbiorowi szkiców Stawara Artur Międzyrzecki ${ }^{26}$. Nie wnosi on jednak do dyskusji nic ponad to, co już zostało wcześniej powiedziane. Jedyne, na co należy zwrócić uwagę, to podnoszone przez wszystkich „recenzentów” silne osadzenie krytyki Brzozowskiego w realiach społeczno-politycznych epoki. I chociaż Międzyrzecki nie pisze o tym wprost, to wiadomo, że chodzi tu o silne zakorzenienie aparatu krytycznego Stawara w filozofii marksistowskiej ${ }^{27}$.

że się właśnie z ich po trosze wspomnieniowym charakterem, a więc specyficzną konwencją gatunkową

S. Treugutt Skromność i upór, s. 6. A. Międzyrzecki O Brzozowskim, „Świat” $1961 \mathrm{nr} 25$, s. 19. ce marksistowskiej. Oczywiście pierwszą narzucającą się odpowiedzią jest reakcja alergiczna wywołana dominacją tego typu dyskursu między rokiem 1948 a 1955. Nie tłumaczy to jednak szeregu zjawisk, a tym bardziej nie wyjaśnia, dlaczego niektórzy mówili o tym wprost. 
Zdecydowanie najdłuższą recenzją zbioru szkiców jest tekst Zbigniewa Żabickiego, opublikowany na łamach „Nowej Kultury” w 1961 roku $^{28}$. Podobnie jak Stempowski, Treugutt i Międzyrzecki, Żabicki z ogromnym uznaniem wypowiada się o Stawarze, jego postawie osobistej, ale nade wszystko o metodologii, którą posługiwał się w swojej publicystyce dotyczącej zarówno spraw kultury i literatury, jak i życia społeczno-politycznego. To, co różni głos Żabickiego od wcześniej omawianych, to podkreślenie znaczenia przeprowadzonej krytyki dla współczesności. Owa aktualność dotyczy przede wszystkim opisywanego przez Brzozowskiego typu człowieka - inteligenta, który ma taką samą siłę oddziaływania w latach 6o. XX wieku, jak w jego początkach. Zaletą krytyki Stawara jest zdaniem Żabickiego pytanie „o rzeczywiste znaczenie Brzozowskiego w dziejach polskiego intelektualizmu. Znaczenie to widział [Stawar - przyp. P.R.] nie w ideach Brzozowskiego - te są przeważnie zapożyczone, pełne sprzeczności i nie układają się w żaden system lecz w tym, że autor Płomieni był postacią niezwykle typową dla środowiska społecznego i atmosfery intelektualnej swego czasu"29. Za twierdzeniem tym kryje się przekonanie, że mimo realnej zmiany systemowej i społecznej, jaka dokonała się po II wojnie światowej, polska kultura nadal pozostaje w zaklętym kręgu tych samych idei, tych samych typów kulturalnych i osobowych, tych samych wzorców, co za czasów autora Idei. To - zdaniem Żabickiego sprawia, że nie tylko sam Brzozowski jest niezwykle ważny dla myślenia o teraźniejszości, ale także krytyka przeprowadzona przez Stawara, która ze względu na swoją metodologię wydobywa i stawia w zupełnie nowym świetle problemy, które można byłoby uznać za już dawno przebrzmiałe. W recenzji Żabickiego pojawia się także zastrzeżenie, co do pewnych wątków mocno krytykowanych w eseju O Brzozowskim. Dotyczy to przede wszystkim zagadnienia filozofii pracy, która zdaniem Żabickiego wymierzona była w cierpiętniczą jej wersję, tak popularną w okresie pozytywizmu i Młodej Polski, a więc w której sam Brzozowski wyrastał. Recenzent „Nowej Kultury” pisze o tym w sposób następujący:

Nienaski i Judym musieli cierpieć z samej natury swych obowiązków społecznych i dopiero cierpienia nadawały spełnianiu tych obowiązków wysoki walor moralny. Brzozowski usiłował przekształcić ten tragizm w heroizm optymistyczny. Rozumiał, że indywidualizm młodopolski 
bezapelacyjnie skazany jest na wymarcie; bolał nad tym jak każdy, kto zostaje ugodzony w system wartości najbardziej mu bliskich, ale jednocześnie szukał pociechy w optymistycznej wizji przyszłości: czasów, gdy całkowicie zlikwidowana zostanie izolacja pomiędzy pracą umysłową a fizyczną, pomiędzy twórczością intelektualną a „codziennym” życiem społecznym. ${ }^{30}$

Oczywiście można się spierać, czy polemika Żabickiego nie jest prowadzona trochę obok podstawowych zarzutów Stawara wobec Brzozowskiego, nie zmienia to jednak ogólnej kwestii, że autor artykułu z „Nowej Kultury” twórczo stara się wejść w polemikę z uznanym autorem. Jest to moim zdaniem najlepsze świadectwo ciągle żywej myśli autora Ptomieni, która po ponad pół wieku potrafiła wzbudzać równie silne emocje, jak w okresie swojego powstawania.

Pojawienie się szkicu Stawara O Brzozowskim na mapie intelektualnej powojennej Polski stało się niezwykle ważnym wydarzeniem. I chociaż jego recepcja rozczarowuje ${ }^{31}$, to jest sygnałem, że podnoszone w opublikowanym w 1961 roku szkicu tezy, mają ogromną żywotność. Stawar przywraca młodopolskiego filozofa do sfery intelektualnych debat. Nie robi tego jednak jako jego gorliwy wyznawca, ale krytyk potrafiący dostrzec wiele pozytywnych aspektów tej myśli, nie popadając w ślepy krytycyzm. Ich dostrzeżenie wiązało się jednakże z koniecznością przebycia krętej ścieżki życia i historii, które zmieniły perspektywę postrzegania. I choć ponowne zajęcie się Brzozowskim ukazuje ewolucję w poglądach Stawara, to jednocześnie jest świadectwem tego, że można nadal pozostawać przy ideałach młodości mimo ich zdewaluowania przez wydarzenia historyczne. To umacnianie i przywracanie literackiej krytyki marksistowskiej w swej nieortodoksyjnej wersji zdecydowanie należy uznać za jedno z największych osiągnięć Stawara po przełomowym dla historii Polski Październiku.

30 Tamże.

31 Oprócz wspomnianych już not do recepcji Brzozowskiego przez Stawara badacze odnoszą się zazwyczaj krytycznie i na marginesie głównych rozważań. 


\section{Abstract}

\section{Paweł Rams}

THE INSTITUTE OF LITERARY RESEARCH OF THE POLISH ACADEMY OF SCIENCES (WARSAW)

Andrzej Stawar's Postwar Portrait of Brzozowski

Andrzej Stawar wrote two studies on Stanisław Brzozowski. The first appeared in the monthly Dźwignia in 1928, while the second was published as a single essay in 1961. Rams highlights the similarities and differences between these two texts. He also examines biographical and historical factors that influenced the two interpretations, linking them with the author's social and personal experience.

\section{Keywords}

Stanisław Brzozowski, Andrzej Stawar, reception, marxism, Polish People's Republic 